\title{
Recycling, waste management and urban vegetable gardens
}

\author{
A. Sgobbo \\ Department of Architecture, University of Naples "Federico II", Italy
}

\begin{abstract}
Waste management is an issue where several technical, technological but also social and cultural factors contribute to make it complex, while the concentration of waste production in big cities mainly gives it an urban and metropolitan dimension. Remarkable difficulties can be found in the scarce motivation of the citizens to actively participate in the process of trash separation and collection as well as in the dislike they feel towards the systems and facilities dedicated to waste processing. This paper reports on research in this subject carried out at the University of Naples thanks to a scientific cooperation agreement with the Dutch multinational company Corrio. The verified thesis showed the existence of a close relationship between direct and tangible motivations and the users' attitude to trash separation. The results were significantly above those expected to be obtained through coercive methods or, even worse, through the promise of an abstract general benefit. The above-mentioned research also brought the implementation of a prototype made up of a playful but at the same time educational urban vegetable garden of around 800 sq. $m$ with a virtuous management system of organic household waste. The experiment, named Orto in Campania, showed the real effectiveness of the proposed solutions with a strong motivational value for the citizens' involvement but also the mutability of it both in well-established and in new urban areas. The success was so huge that this installation, intended as temporary, is still on course after more than five years.

Keywords: reduce, reuse, recycle and recovery (4Rs).
\end{abstract}

\section{Introduction}

That of waste is a question which several technical, technological but also social and cultural factors contribute to make complex, while the concentration of waste 
production in big cities mainly gives it an urban and metropolitan dimension. In Campania the problem of waste is strictly connected with the presence of wellestablished criminal organizations that have disposed industrial and dangerous waste in the area known as Terra dei Fuochi (Land of Fires), a media designation due to the heaps of waste that are frequently set to fire [1].

After the dump era, the waste management process is now made up of three standard phases: trash separation and collection, recycling of the useful parts, disposal of the remaining parts. The way in which such processes take place as well as the common difficulties we face [2] varies from system to system.

As far as household and industrial waste are concerned, the phase of trash separation and collection is generally developed through the so-called door-todoor system, according to which waste are brought to the company managing their collection process in the same place where they are produced. In more advanced areas the very users may also bring waste to some central storage points which, in Italy, are ironically defined as "environmental islands" [3]. In both cases the decisive factor of the success of this initiative can be found in the citizens' attitude to separate trash a priori and, therefore, as Giannini underlines [4], in the ability of public authorities to force/to motivate such attitude. Indeed the trash separation and selection system ex post is prohibitive, except for those countries where labour cost is lower than the expected benefit, such as for instance Africa, India and the South-American countries, where manual recycling of e-waste is frequently carried out, as described by Cumo et al. [5].

Even the disposal of those waste that cannot be directly re-used shows remarkable difficulties beyond the technical aspect in itself. Generally speaking, the process envisages the transformation into inert material through incineration as far as dry components are concerned and through digestion/oxidation as far as organic components are concerned. Such components, in fact, show combustion difficulties connected with the high content of water resulting in a higher environmental impact of the whole system [6] or in the need to adopt systems with a rotary combustion chamber which, as underlined by Williams [7], are not suitable for the processing of the remaining parts of waste.

In both cases the main difficulty faced during the implementation of such systems results in the strong opposition by the citizens, who can only see and feel huge damages for the environment, dangers for their health, inconveniences due to miasmas and general decay [8,9]. Such an attitude is more and more emphasized in those territories where the waste management carried out by criminal organizations for decades has deeply threatened the citizens' confidence in local institutions [10].

We recently had a research opportunity on this subject at the shopping district owned by Còrio, a Dutch multinational company working in the field of retail real estate, within a scientific cooperation agreement entered into with the Department of Architecture of the University of Naples "Federico II": this brought to the implementation of a prototype made up of a playful but, at the same time, educational urban vegetable garden of around 800 sq. $\mathrm{m}$ with a virtuous management system of organic waste. 
The verified thesis showed the existence of a close relationship between direct and tangible motivations and the users' attitude to trash separation: the results were significantly above those expected to be obtained through coercive methods or, even worse, through the promise of an abstract general benefit.

Many studies were carried out on questions concerning the environmental effectiveness of the processes of re-use, reduction and recycling of urban waste. Several researches dealt with the technical aspects of recycling of those materials which can be immediately re-used (e.g. Mark E. Schlesinger at Missouri University deals with aluminium recycling [11] or the thorough close examination by Paul T. Williams [7]), of the use of incinerators and organic waste in order to obtain energy $[12,13]$, of the inefficiencies that still today can be noticed in the whole cycle (a subject that MacBride [14] at the New York University has recently dealt with and that in Italy can be found in the annual report issued by the ISPRA, the Advanced Institute for Environmental Protection and Research [15]), of the alternative solutions to digestion for the disposal of organic components (e.g. the growing interest towards vermicomposting shown by Quintern [16] as well as by Soobhany et al. [17]). On the contrary, the contributions dealing with the attitude towards trash separation from the point of view of the citizens and with the results that may be obtained through suitable urban politics are quite limited. Among the main contributions an interesting study carried out in Portugal [18], parts of the research by Blackman [19] and the studies at the University of Naples on the implementation of advanced solutions of a multiscale system integration in urban areas are noteworthy [20].

\section{Case study: the vegetable garden "Orto in Campania"}

The Parco Commerciale Campania (Campania shopping district), the biggest retail structure of Southern Italy, was developed according to the typical scheme of similar settlements within the same region, as a result of the adaptation to the local law [21] of the French traditional model which became popular in Europe [22, 23]. Around the central mall, structured on a two-level building of more than 40,000 sq. m per level with a big central gallery, you can find other single-theme malls connected one another by an external promenade. The whole district is structured so to lead the user from a mall to the other remaining wide enough in order to meet the functional separation requirements necessary not to exceed the strict dimensional limits imposed by the related rule. The peculiarity of the whole structure may be found in the progressive growth of its attraction abilities, also thanks to the settlement in the neighbourhood of La Reggia, the biggest Factory Outlet Village of Central and Southern Italy, and of the international goldsmith's art centre Tarì. This, together with the shortage of playgrounds and leisure services in the densely populated neighbouring towns [24], makes the presence of people exceed 20.000 units in rush days and hours. The core of the district is represented by a wide covered area on two levels named "Piazza Campania", which, apart from being the classical food court, hosts the most important events and allows access to night entertainment activities (multiplex cinema, amusement arcades, exhibition rooms and a theatre). Right at the entrance of "Piazza Campania" you 
can find the area where the experimental prototype developed within the research described in this article was installed.

The shopping district management proposed the Department of Architecture a cooperation in order to implement an external place to let children play. This project should be developed in line with the retail needs of this special regional area where the applied strategy is influenced by the social context. Indeed, while in the Northern Italian regions the goal is to attract a wide audience, providing general and economic services, the need to select the audience in the Southern Italian areas makes such places for children currently evolve towards more elite forms, both from a cultural and from an economic point of view. The classical playground with simple elements such as slides, inflatable facilities and courses with recreational elements gives its seat to high-technology amusement arcades, with experiences of augmented reality that can be compared to those you can find in the best amusement parks, or is more and more equipped with educational places and rooms for reading and hosting exhibitions [25].

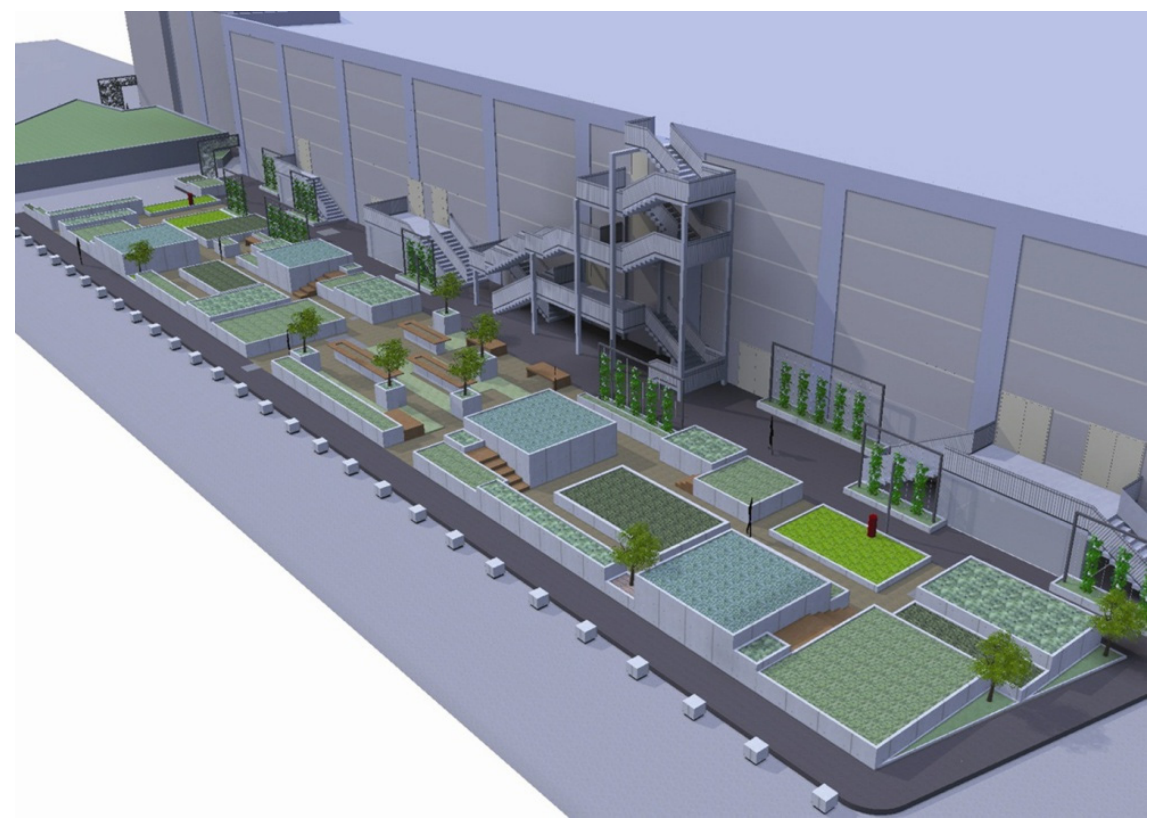

Figure 1: Rendering of the three-dimensional vegetable garden designed by the research group on the right corner of the main entrance of the shopping district owned by the Dutch multinational company Còrio.

On that occasion the district management, given the daily need of disposing considerable quantities of food waste and the scarce results of trash separation and collection, also drew the attention of the research group to the need of developing innovative solutions in this field. Indeed it was noticed that, though it was possible to carefully check the waste that were directly disposed by commercial operators, 
towards users and customers there was no such possibility. The containers located in the mall to host different kinds of waste were scarcely or very badly used by customers; moreover, peaks of total inefficiency could be registered in rush days. The percentage of trash separation and collection was around $70 \%$ for shop retailers, while it was less than $20 \%$ for the waste produced by customers that, however, represented the greatest part.

In order to meet the asked requirements and, at the same time, to gather effective data the research group, organized by Professors F. D. Moccia and A. Sgobbo with the cooperation of nine brilliant students of Architecture, proposed the implementation of a three-dimensional playful and educational urban vegetable garden of around 800 sq. m (figure 1), completely built with recycled rejected manufactured products, laid over the pre-existing grounds and integrated within the pedestrian circulation system as well as within the facilities of the shopping and trade centre.

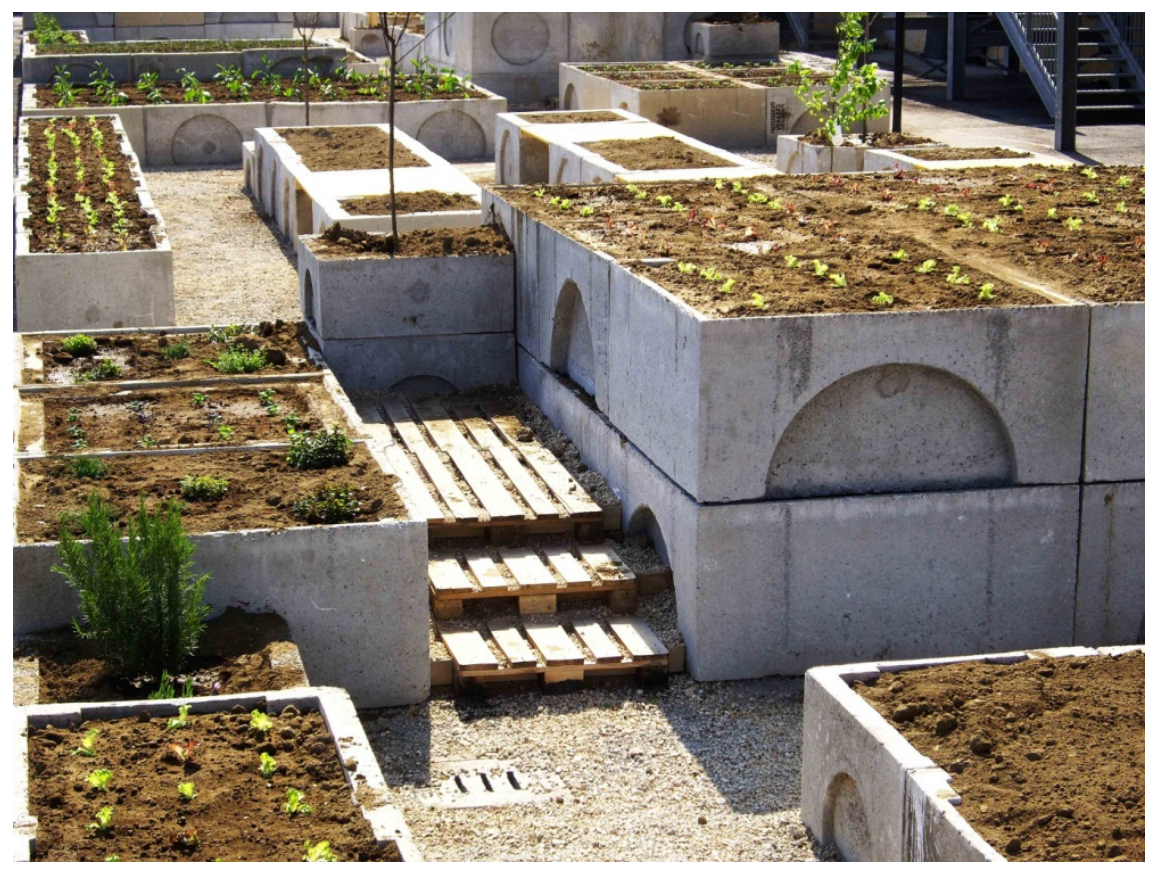

Figure 2: A view of the Orto in Campania in the initial phase of the cultivation cycle of vegetables. In the centre you can see the particular of the stairs implemented with old wooden pallet banks

The structure is made up of concrete prefabricated defective basins which should have been destroyed. Such drain basins, both individually and assembled in more or less complex groups, were used to form the cultivation tanks, distributed on more levels and connected by an unsurfaced path. Old wooden 
banks, which are employed for pallet transportation and cannot be re-used any longer, were then used to build the stairs connecting the different paths and bringing to the elevated clear spaces raised to observe the above-mentioned tanks. Carpentry wooden axes, that had already been used and should have been disposed, form the support portal for climbing vegetables. Last but not least, old shuttering panels form the banks on which small plants are treated for educational purposes.

As far as the synergy between the vegetable garden and the cycle of waste collection and disposal is concerned, the structure is functionally connected with a modern facility producing biogas from anaerobic digestion of household organic waste; such facility has been recently built, arousing endless controversies, a few hundred meters far from the parking place of the shopping centre. Here, inside a warehouse that is always maintained in depression in order to avoid stinking emissions, the collected waste are selected, on a vibrating belt, in order to avoid any foreign remains. Before being expulse, the air inside the warehouse is completely filtered and purified. This is made with moist scrubbers using washing solutions aimed at removing odor-emitting compounds through absorption and oxidation, as well as with mist scrubbers in which the washing solution is vaporized into very fine drops that, once full of odor-emitting compounds, fall to the bottom of the filtration chamber.

The selected waste are preserved in anaerobic digestion tanks made up of aluminium-based reinforced concrete sarcophagi: these are closed by watertight pneumatic doors and they have heating pipes inside the walls. Here waste are sprinkled with small quantities of percolate (used as bio-activator) and remain at a temperature of around 55 degrees for further 14 days. In this phase biogas is formed, a gaseous fuel containing a percentage of methane, usually between 50 and $60 \%$, used in a co-generator in order to produce power and heat [26].

The obtained composting is then transferred to another warehouse for aerobic oxidation post-treatment. Here the material slowly follows a path limited by cement embrasures and it is constantly inflated with warm air. At the end of the path the composting is totally inert and, after a further fine selection to remove any foreign waste, it is packed as agricultural fertilizer. In the case of the Campania shopping district the product is brought back to its place of origin and mixed with land to fertilize the vegetable garden.

\section{Method}

In order to verify the thesis we thought about connecting the functioning of the vegetable garden to the waste separation and collection made by the customers by directly involving a careful, steady group of users able to effectively condition the behaviour of the others: children. Besides, the idea of a gardening space with vegetables instead of the classical garden came out from the will to implement an area dedicated to our children in which we could also spread the message of the organic quality of the products sold by the shops in the mall. Thanks to the cooperation of Slow Food both the customers of the shopping district and the children of the neighbouring schools were playfully involved in the management 
of the vegetable garden and took part in guided tours allowing them to handle vegetables and even plant some of them. Moreover, both during the tours and through posters in the shopping gallery, it is explained to the customers that by throwing organic waste in the right containers causes them to be transformed into the composting used to keep the vegetable garden alive and luxuriant. The whole biogas production process, the implications of an ineffective waste management on health and environment as well as the advantages of keeping a virtuous behaviour at home are also described.

Among the indicators selected to measure the incidence of the prototype on the consumers' attitude to actively participate in the waste management process the most relevant are: the percentage of correctly disposed organic waste, with reference only to customers, compared to the total amount of produced waste; the percentage of all kinds of separated waste compared to the total amount of produced waste; the active participation in the blog concerning the vegetable garden [27], both in terms of unique visitors and of subscribed people; the percentage of wrong elements found in the organic waste brought to the neighbouring anaerobic digestion facility.

Such measurements were carried out over a period of 5 years both at daily, monthly and yearly intervals in order to have further the possibility to verify the incidence on the phenomenon during media events, moments of crisis of the regional waste collection system, etc. This also allowed one to evaluate and adequately check the fluctuations due to the novelty effect. The same measurements were used to compare the different data: with reference to the same shopping and trade centre in the previous five years; with reference to other malls in the same territory; with reference to other experiences of urban vegetable gardens.

\section{Analysis of the obtained results}

Once the construction was completed in April 2011, the vegetable garden undoubtedly had a great architectural impact. Moreover, both the customers' children coming to the shopping centre and the pupils of the schools visiting it were immediately attracted by the playful and educational qualities of the installation and could also have a try at intensive interaction activities ranging from the possibility to touch vegetables, to know their vital cycle, to learn their form, colours and odors beyond the distortions urban life forced them to, to the possibility to directly plant the future harvest. Some cultivation tanks were adopted by a classroom managing their needs over time, fertilizing them with composting and periodically weeding them.

The impact on the percentage of the organic waste that were correctly disposed by customers compared with the total amount of the produced organic waste, without taking into account the peak of the first opening week, began to grow more and more starting from the end of the third month. After 14 months the value of the yearly data was around $82 \%$. The value of the monthly data reveals the close relationship with the vegetable garden cycle highlighting peaks of $93 \%$ during spring and autumn and negative records of $68 \%$ during rainy or cold months when 
less visitors interact with it. On a daily basis, the best results were recorded during working days when the percentage of the retained customers was higher than that of the occasional ones [28].

The compared analysis of the above-mentioned results highlights the actual existence of a motivational connection with the vegetable garden. It is above all the monthly data that exclude that a closer attitude by customers towards trash separation and collection may just come from the awareness campaigns promoted by the shopping district. Otherwise the fall in the performances registered in the period in which there is no contact with the vegetable garden would not be justified. Even the relationships detected between retained customers and daily results of trash separation and collection bring to such conclusions. In fact the Orto in Campania, rather than occasional customers, mainly affect and stimulate those users who, in time, got to know its qualities and functioning cycle.

The pattern of the data concerning the percentage of wrong materials found in the organic waste brought to the neighbouring anaerobic digestion facility has slowly enhanced. An educational need was highlighted, that is the symptom of the scarce constancy with which trash separation and collection in Campania is ordinarily carried out. At the beginning customers, though motivated, had many doubts of what organic waste actually were, often confusing them with general recyclable waste. On the contrary, when the shopping and trade centre organised information campaigns, not only the quality of trash separation and collection was better, but such a progress also tended to remain steady over time. The same happened when the towns within the 15-minute isochrone of the catchment area of the shopping district, where most of the retained customers live, started to promote awareness actions accompanying the introduction of the door-to-door trash collection system. Definitely, the citizens of Campania not only have no motivation, but they also are not adequately prepared in order to actively participate in the waste management system [29].

The data on the total percentage of trash separation and collection compared with the total amount of junk produced by customers show a pattern corresponding to that concerning the organic part only, and this also concerns all measurement intervals. On a yearly basis, after five years from the beginning of the experiment, such a percentage steadily amounts to $84 \%$; according to the literature $[30,31]$ it is difficult to obtain a better value. This highlights that, where adequate motivations for a careful management of at least one waste typology are given, citizens will naturally feel pushed to take care of the whole trash separation and collection process [32].

The data concerning the participation in the blog were not so useful because the difficulties in managing it by the staff of the district did not give customers the possibility to directly intervene. The result was a scarcely updated and dynamic website visitors became soon tired of.

The compared measurements of the same indicators at other malls within the same territory allowed both to purge the gathered data from the fluctuations connected with secondary events and to evaluate the synergy effects of different initiatives. In fact, there was a limited but perceivable enhancement of the percentage of trash separation and collection in the neighbouring centres; in 
the same way better results were obtained by occasional customers in periods after some events with a high media impact connected with the waste cycle: the crisis of the "Terra dei Fuochi" in 2013; the sales fall in the agricultural and food sector; the exhibition of the Uffizi museum in Casal Di Principe.

Without taking into account the incidence of the initiative on the economic results obtained by the shopping district, the Orto in Campania also gave unexpected but very important results. First of all the structure, unattended and with an easy access at any time, has never undergone vandalistic actions, thus highlighting the common sense of belonging it aroused thanks to its management form, which involved the participation of everyone. Moreover, the management of the neighbouring waste anaerobic digestion site reported that some citizens, who were then identified as regular customers of the shopping district, frequently and spontaneously brought their organic household waste. Such a behaviour not only indicates the particular level of involvement the prototype could arouse, but also the overcoming of suspicion and unrest [8] citizens usually feel towards such facilities.

\section{Conclusions}

The experiment "Orto in Campania" showed the effectiveness of highly motivational value solutions in which everyone can take part in order to push citizens to actively participate in the process of waste separation, collection and disposal. But the best result was in the educational ability showed. Such observations highlight the mutability of the experiment in both well-established and new urban settlements in order to overcome the citizens' scarce attitude to carry out trash separation by themselves. Trash separation and collection is mainly felt as an imposition with obligations and prohibitions, accompanied by an increase in the management costs and therefore in taxation and aimed at obtaining an often abstract and not immediate benefit for the environment. At the same time the widening of urban green spaces, such as parks and gardens, is a considerable deterrent for the investment of the already scarce resources of Local Bodies towards high management and maintenance costs [33]. From here we proposed the idea according to which urban vegetable gardens and biogas production facilities, above all those implemented in CCHP systems (Combined Cooling, Heating and Power), could become new centres to be steadily proposed in order to meet the needs of green infrastructures inside urban areas [34].

A further incentive to the concrete implementation of such solution is offered by the recent technological evolution of organic waste anaerobic digestion facilities which made such installations more and more consistent with urban realities. In the most recent project model, in fact, the whole digestive structure is undergrounded and motorized, so that only the warehouse dedicated to waste receipt are visible. This is completely isolated and connected outside through depression filters making the working function of the facility consistent with the neighbouring houses [26]. The choice of the CCHP system is particularly effective for the installations to be implemented in Southern cities, where the energy consumption for cooling used during summer is higher than that for heating used 
during winter periods. The advantage is determined by the huge enhancement of the effectiveness of the energy production process. Indeed it is known that, in a traditional facility, only $35 \div 38 \%$ of the primary energy supplied to the system is actually transformed into power, because the remaining part is dissipated into the environment. The CHP facility is able to reduce the dissipated part up to around 15-20\%. The CCHP facility introduces a further advantage: part of the recovered heating is employed in the production of refrigerated water thanks to an absorption freezing cycle [35]. In such a case the energy conservation is represented by the lower quantity of primary energy employed in the freezing cycle thus adding to the effectiveness of the co-generation system a greater effectiveness in freezing production.

A district heating-cooling system could distribute primary fluids to the inhabitants thus producing the effect of a widespread participation that, in the example of the shopping and trade centre in Campania, showed it could have remarkable positive results. Indeed citizens would become the main suppliers of organic household waste getting both direct benefits in economic terms and indirect benefits in educational terms. From the economic point of view, for instance, according to the quantity of supplied organic waste, citizens could receive some credits that may be then exchanged with the heating received from the district heating-cooling system; in educational terms it is easy to imagine that the citizens' engagement in organic waste separation would result in a general enhancement of the attitude towards the separation of all kinds of waste.

Last but not least, the integration of the biogas facility with urban vegetable gardens may have further benefits on the community. As previously highlighted, in fact, the need of green areas in the cities is opposed to the scarcity of economic resources available to Local Bodies. Parks and gardens, apart from requiring huge initial investments, imply maintenance and management costs that are often inconsistent with the actually available resources. Urban vegetable gardens, on the contrary, offer an effective alternative to the traditional model of conceiving urban green areas [36], above all if they are managed with the active participation and sponsorization of citizens, blocks of flats and schools. The experience of the shopping district Campania showed how, even in a difficult reality from a social point of view, the citizens' attitude towards the respect of green areas is, in the case of a vegetable garden, significantly higher than the attitude towards parks and gardens. Moreover, a direct management and maintenance boost constant control forms that are completely inconceivable if managed by Local Bodies.

\section{References}

[1] Giordano, A., \& Chiariello, P., Monnezza di Stato. La Terra dei fuochi nell'Italia dei veleni, Minerva Edizioni: Bologna, 2014.

[2] Morrissey, A. J., \& Browne, J., Waste management models and their application to sustainable waste management. Waste management, 24(3), pp. 297-308, 2004. 
[3] Cerrina Feroni, G. (ed.), Produzione, gestione, smaltimento dei rifiuti in Italia, Francia e Germania tra diritto, tecnologia, politica, G. Giappichelli Editore: Turin, 2004.

[4] Giannini, F., L'esercito italiano e la crisi dei rifiuti in Campania. Nulla si butta, tutto si ricicla. Rifiuti: le criticità, la governance e la partecipazione, ed. A. Angelini, Franco Angeli: Milano, pp.137-143, 2009.

[5] Cumo, F., Sferra, A., \& Pennacchia, E., Uso, disuso, riuso. Criteri e modalità per il riuso dei rifiuti come materiale per l'edilizia, Franco Angeli: Milan, 2015.

[6] Buekens, A., Incineration Technologies, Springer Science \& Business Media: New York, 2013.

[7] Williams, P.T., Waste Treatment and Disposal, John Wiley \& Sons: Hoboken, 2013.

[8] Rahardyan, B., Matsuto, T., Kakuta, Y., \& Tanaka, N., Resident's concerns and attitudes towards Solid Waste Management facilities. Waste Management, 24(5), pp. 437-451, 2004.

[9] Kiel, K. A., \& McClain, K. T., House prices during siting decision stages: the case of an incinerator from rumor through operation. Journal of Environmental Economics and Management, 28(2), pp. 241-255, 1995.

[10] Ruzzenenti, M., L'Italia sotto i rifiuti. Brescia: un monito per la penisola, Editoriale Jaca Book: Milan, 2004.

[11] Schlesinger, M.E., Aluminum Recycling. Second Edition, CRC Press: Boca Raton, 2013.

[12] Niessen, W.R., Combustion and Incineration Processes: Applications in Environmental Engineering. Fourth Edition, CRC Press: Boca Raton, 2010.

[13] Luk, G.K., \& Bekmuradov V., Energy products from source-separated organic waste. WIT Transactions on Ecology and the Environment, 180, pp. 65-76, 2013.

[14] MacBride, S., Recycling Reconsidered: The Present Failure and Future Promise of Environmental Action in the United States, MIT Press: Cambridge, U.S.A., 2011.

[15] Lanz, A.M., \& Santini, A.F., Produzione e raccolta differenziata dei rifiuti urbani. Rapporto Rifiuti Urbani 2014, ISPRA: Roma, pp. 21-70, 2014.

[16] Quintern, M., Full scale vermicomposting and land utilisation of pulpmill solids in combination with municipal biosolids (sewage sludge). WIT Transactions on Ecology and the Environment, 180, pp. 65-76, 2013.

[17] Soobhany, N., Mohee, R., \& Garg, V. K., Recovery of nutrient from Municipal Solid Waste by composting and vermicomposting using earthworm Eudrilus eugeniae. Journal of Environmental Chemical Engineering, 3(4), pp. 2931-2942, 2015.

[18] Lima, M.L., \& Marques S., Towards successful social impact assessment follow-up: a case study of psychosocial monitoring of a solid waste incinerator in the North of Portugal. Impact Assessment and Project Appraisal 23(3), pp. 227-233, 2005.

[19] Blackman, T., Urban Policy in Practice, Routledge: London, U.K., 2013. 
[20] Sgobbo, A., Infrastrutture ecologiche: approccio urbanistico alla sostenibilità degli insediamenti residenziali. La città sobria, ed. F.D. Moccia, Edizioni Scientifiche Italiane: Naples, pp. 255-262, 2013.

[21] Sgobbo, A., Evoluzione della Pianificazione Urbanistica e Territoriale in Campania". Urbanistica. Interpretazione e processi di cambiamento, F.D. Moccia, Clean: Naples, pp. 311-324, 2012.

[22] Laroche, M., Selected issues in modeling consumer brand choice: the extended competitive vulnerability model. Essay by Distinguished Marketing Advances, eds. A.G. Woodside \& E. Moore, Elsevier Science: New York, pp. 69-114, 2012.

[23] Yaari, M., Rethinking the French City: Architecture, Dwelling, and Display After 1968, Editions Rodopi: Amsterdam, 2008.

[24] Mangoni, F., \& Sgobbo, A., Pianificare per lo sviluppo. Un nuovo insediamento ai margini della metropoli, Edizioni Scientifiche Italiane: Naples, 2013.

[25] Moccia, F.D., \& Sgobbo, A., La polarizzazione metropolitana. L'evoluzione della rete nella grande distribuzione verso un sistema policentrico sostenibile, Liguori: Napoli, 2013.

[26] Sgobbo, A., Un impianto di biogas in ogni quartiere. Urbanistica informazioni, 38(232), pp. 41-42, 2010.

[27] L'orto in Campania. www.ortoincampania.it

[28] Bellintani, S., Il mercato immobiliare dei centri commerciali. Asset, Property e Facility management nella Grande Distribuzione, FrancoAngeli: Milano, 2010.

[29] Gribaudi, G., Il ciclo vizioso dei rifiuti campani. il Mulino, 57(1), pp. 1733, 2008.

[30] Reschovsky, J. D., \& Stone, S. E., Market incentives to encourage household waste recycling: paying for what you throw away. Journal of policy analysis and management, 13(1), pp. 120-139, 1994.

[31] Bell, J., Huber, J. C., \& Viscusi, W. K., Trends in Household Recycling of Cans, Paper, Plastic, and Glass; US and State Data 2005-2012. Vanderbilt Law and Economics Research Paper, (14-3), 2014.

[32] Morrissey, A. J., \& Browne, J., Waste management models and their application to sustainable waste management. Waste management, 24(3), pp. 297-308, 2004.

[33] Sgobbo, A., Analisi economica e finanza di progetto per la gestione dei parchi urbani. La valorizzazione dei Parchi Urbani, ed. A. Claudi de Saint Mihiel, Clean Edizioni: Naples, pp.183-193, 2011.

[34] Moccia, F.D., \& Sgobbo, A., Flood hazard: planning approach to risk mitigation. WIT Transactions on the Built Environment, 134, pp. 89-99, 2013.

[35] Maraver, D., Sin, A., Sebastián, F., \& Royo, J., Environmental assessment of CCHP (combined cooling heating and power) systems based on biomass combustion in comparison to conventional generation. Energy, 57, pp. 1723, 2013.

[36] Stroppa, C., Orti urbani: una risorsa, Franco Angeli: Milan, 1996. 